\title{
A DESIGN OF SMART FLIPPED CLASSROOM TEACHING MODE IN COLLEGE ENGLISH READING CLASS
}

\author{
Zhong Xue \\ College of Foreign Studies, Guilin University of Electronic Technology \\ Corresponding Author E-mail: englishzx@qq.com
}

This is an open access article distributed under the Creative Commons Attribution License, which permits unrestricted use, distribution, and reproduction in any medium, provided the original work is properly cited

\section{ARTICLE DETAILS}

Article History:

Received 12 November 2017 Accepted 12 December 2017 Available online 1 January 2018

\section{ABSTRACT}

Smart flipped classroom is the trend of college English teaching reform but seldom applied in college English reading class. This paper first states the urgency of English reading class reform and the theoretical framework of smart flipped classroom. By constructing a "Three Three" teaching mode-three smart platforms, three stages of smart learning and three smart learning modes of smart learners, this paper focuses on the design of the flipped classroom in English reading class in pre-class, in-class and post-class in order to enhance students' all-round ability in English reading.

\section{KEYWORDS}

smart education, flipped classroom, English reading class

\section{INTRODUCTION}

According to the National Medium and Long-Term Educational Reform and Development Program (2010-2020), college graduates should be acquired with international horizon, foreign language proficiency and international business competency. As international talents, students are required to detect, analyze and solve questions logically and systematically with English. Therefore, college English, especially college English reading class, aims at developing students' skimming and scanning reading ability and logical ability of hypothesis, judgment, analysis, generalization, inference and testing by English, meets the requirement of the nation. However, after years of English teaching reform, the reading ability of Chinese college students haven't improved evidently. Take the students of Guilin University of Electronic Technology as an example, the first grade students rated only $37.11 \%$ in reading part in the college entrance model band-4 test; the graduates quoted few foreign references in their thesis; graduates could not read and analyze English information freely in the Engineering Education Accreditation. The reason for these deficiencies in English reading comes from insufficient systematic reading practice. In traditional English reading class, the limited class hours and oceans of reading texts and materials bring great burden to teachers and students. The teachers rush to explain as many language points as possible to students in class and assign many reading practice homework after class in objective questions form. The students are forced to roughly accept a lot in the class without enough time to think and internalize as their own knowledge. In this case, it is urgent to take an English reading class reform by means of smart education resources.

\section{LITERATURE REVIEW}

The concept of "Smart Education" originates from IBM in 2009. Based on a research, smart education is the education that, by constructing technological blending study environment, enables teachers implement efficient teaching strategies and enables students get appropriate personalized study service and experience, thus cultivate students as talents with accurate value orientation, great action ability, excellent thinking ability and profound creativity potential [1].

Based on the above definition, smart education mainly consists of smart environment, smart teachers and smart learners. Smart environment includes smart terminals, smart classroom, smart campus, smart labs and smart cloud platforms. Smart teachers refer to knowledgeable teachers with smart education ideas, proficient information technology and creation-driven teaching methods. Smart learners are learners who can absorb and use what they learn in smart classroom and turn it into their own knowledge. On the basis of smart environment constructed by information technology, smart learners become talents who are good at learning, cooperation, communication, researching, creation and problem solving under the promotion of smart teachers with their creative smart teaching strategies. Smart education is quality-orientation education that deepens and optimizes the era of information, knowledge and data.

After the concept of smart education was raised, a researcher brought out the concept of cycled flipped classroom to flip the stage of knowledge impartment with the stage of knowledge internalization (to flip teach first then learn into learn first then teach) [2]. The first MOOCS opened in the Coursera by University of California, Berkeley in 2012 marked the invention of flipped classroom era. In 2013, Professor Armando Fox from the same university created the SPOC (Small Private Online Courses), which combined the resources from MOOCS with teaching face to face in the classroom, to reform the teaching mode and improve teaching quality by flipped classroom.

The concept of smart education coincides with China's education development plan, that's why it is widely applied in all levels and all subjects in China [3]. Take the college English flipped teaching system as an incident, many colleges currently apply or develop their own foreign languages smart platforms to form an integral college English curriculum system, such as college English teaching platform, college English teaching administration platform, smart English writing evaluation system, college English teaching repository, micro-lecture making system and college English testing and training system [4]. However, the teaching mode, curriculum design and teaching effect evaluation of college English flipped classroom that rely on these smart platforms are mainly applied in listening and speaking or writing \&translation teaching [5]. Few research and practice are processed in English reading flipped classroom. So, what the smart platforms can do for college students' English reading before class, how to make the English reading class more efficient by smart flipped classroom, how to further practice and test students' reading 
ability and get quick feedback are questions the paper tries to explore [6].

\section{CONSTRUCTION OF TEACHING MODE}

A "Three Three" teaching mode is constructed for college English reading class (see Figure 1), that is, Three platforms (UNIPUS platform, Rain classroom program and Smart Learning Platform), three stages of smart teaching design (pre-class, in-class and post-class) and three smart learning modes of smart learners (self-learning, group-cooperation learning and immersed learning).

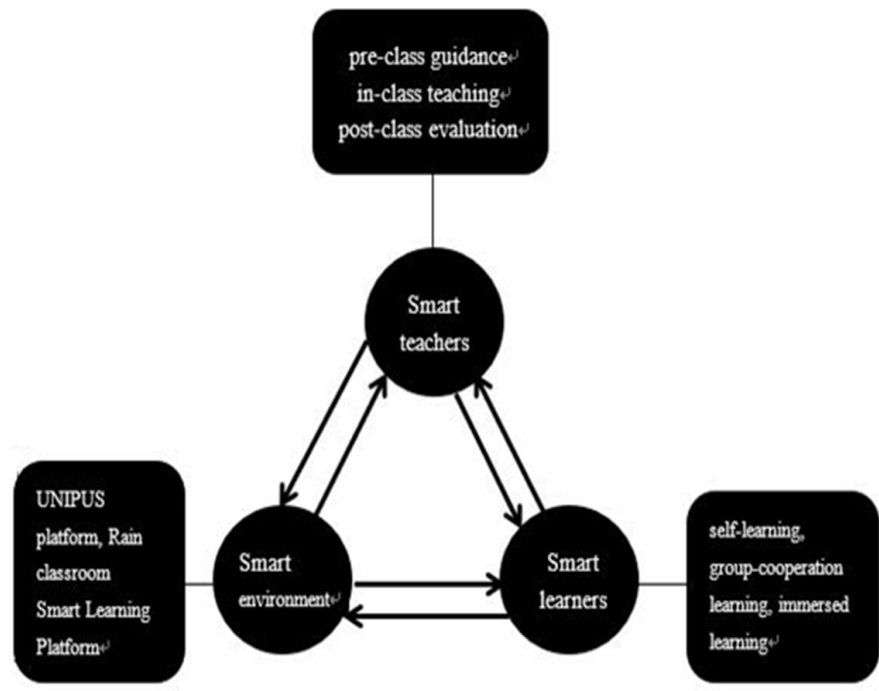

\section{DESIGN OF TEACHING MODE}

\subsection{Three Smart Platforms}

The teaching mode mainly relies on UNIPUS platform, Rain classroom program and Smart Learning Platform to enhance students' reading ability before class, in class and after class. UNIPUS platform is designed by Foreign Language Teaching and Research Press and matched with the text book New Horizon College English Reading and Writing (The Third Edition) which many colleges adopted as their teaching material in English reading class. All the usages of new words, language points, translations, pronunciations of this book can be learned in this platform. Rain classroom program is a program created by Tsinghua University that can be added to Power Point so that the teachers can send their slides of reading materials, exercises and tests via wechat to students and get instant feedbacks and data. Smart Learning Platform is developed by Guilin University of Electronic Technology as an evaluation system mainly in test form. There are seas of model tests for different text books, CET-4, CET-6, GRE, TOEFL, IELTS, etc. Apart from these, students are encouraged to proceed self-learning by referring to other online resources recommended by teachers. The campus is wi-fi covered, which enables students to learn anywhere any time with smart phones, computers, ipads, etc.

\subsection{Three stages of Smart English Reading Flipped Classroom}

The teaching procedure is divided into three stages: pre-class, in-class and post-class.

\subsubsection{Pre-class stage}

Based on UNIPUS platform, students get cognitive input of English reading material. The teachers assign preparation tasks to students according to English reading teaching goal and students' English levels, such as watching micro-lectures about the reading and writing skills, background information related to the reading text, the usage of new words, language points, translation, etc. It means what is taught in traditional classroom by the teachers now is learned by students themselves before class. In the self-learning process, students develop their abilities of inference, reference, analysis, conclusion, judgment and logics. When students finish learning the reading texts in UNIPUS platform, teachers design fast reading questions and detailed reading questions with Rain Classroom program to check students' ability of skimming, scanning and close reading. The Rain Classroom program enables students finish these reading questions in their smart phones and enables teachers get instant feedbacks from students in their smart phones. The big data provided by
Rain Classroom program offer support to teachers' teaching designs for inclass stage. In this stage, with the assistance of smart learning platforms, teachers can offer lots of proper reading resources to students cater to students' different levels in English reading, while students' self-learning ability is greatly promoted.

\subsubsection{In-class stage}

In the class, the college English reading class is flipped from traditional mode "teacher explains, students listen" into a smart cycled progressive mode: "teacher raises questions---students answer, students discover problems---teacher explains". By analyzing and generalizing students' self-learning performance in pre-class stage, teachers design some applicable and innovative exercises or tests in terms of words single choice questions, sentence translation exercises, grammar true or false exercises, main ideas and paragraphs matching exercises, critical thinking questions and so on in order to examine and strengthen students' ability of analysis, generalization, judgment, hypothesis, inference and logics. These exercises and tests are sent to students through Rain Classroom program in screen or smart phones. Students finish the exercises or tests individually, in groups and in forms of immersed learning. During this procedure, they can discover problems they exist, then turn to teachers for help. Meanwhile, the data collected by Rain Classroom program reflect the existing problems to teachers. The existing problems can be solved immediately in the class with the teachers' explanation, and then practiced further to solidify and internalize as students' own knowledge.

\subsubsection{Post-class stage}

This stage is to solidify and enhance the knowledge to a higher level mainly by examination and evaluation base on the smart learning platform. In this stage, teachers assign tests in smart learning platform to students according to their English reading performance in class and reading levels. The students' English reading skills, understanding of the reading materials and master of the relevant language points can be evaluated in smart learning platform. The smart learning platform provides instant results to teachers and students, which enable them further to discuss and explore the knowledge students are not good at in reading. Students' time spending on this evaluation system are also recorded so that teachers are able to give objective formative assessment to students.

The above procedure is shown in Figure 2.

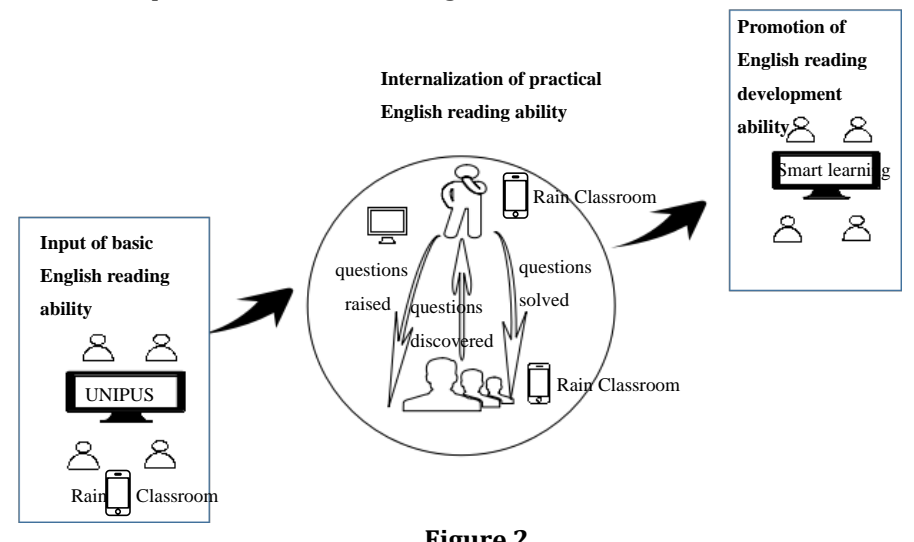

Figure 2

\subsection{Three Smart Learning Modes of Smart Learners}

The three smart learning modes of smart learners are self-learning, groupcooperation learning and immersed learning. Self-learning is encouraged in both pre-class stage and post-class stage. Students are expected to learn the pronunciation, usages and translations of new words, phrases and texts autonomously based on the UNIPUS platform so that their personal reference ability is cultivated. When finishing the fast reading and detailed reading questions individually via Rain Classroom, teachers master students' different levels in text understandings. After the deep teaching and learning in class, self-learning is required again in Smart Learning Platform after class to internalize knowledge as students' own. While in class, group cooperation and group discussion are advocated to spark and stimulate students' deep thinking, thus critical and logical thinking are fostered. On the other hand, teachers design some immersed-in questions to students which enable students immerse themselves in the situation of the authors or the stories of the reading texts to help them read,understand, think and express like the native readers. 


\section{CONCLUSION}

The application of smart flipped classroom teaching mode is a new exploration of the reform in college English reading class. With the booming of network and information technology, it is practicable and can greatly make up the deficiency of traditional English reading class as well as efficiently improve the English reading learning. In the smart flipped classroom teaching mode of English reading class, students are the center of learning who can control their own learning process and always get instant feedback and help from teachers. Therefore, their English reading learning is personalized and motivated. Besides, students self-learning ability and logical thinking are greatly optimized in this procedure.

\section{ACKNOWLEDGEMENTS}

This work is Supported by Project of Guangxi Higher Education College Teaching Reform 2018 "The Research and Practice on Smart Flipped Classroom Teaching Mode in College English Reading Class" (NO. 2018JGB187); Project of Guangxi Higher Education College Teaching Reform 2017 "The Research and Practice of Smart Tests-Oriented Integral College English Teaching Based on Autonomous Online Learning" (NO. 2017JGZ125); Project of GUET Teaching Reform 2018 "The Reform and Practice of the Teaching Mode of New Horizon College English Reading and Writing Base on Rain Classroom" (NO. JGB201816)..

\section{REFERENCES}

[1] Zhu, Z.T. 2016. New Developments of Smarter Education: From Flipped Classroom to Smart Classroom and Smart Learning Space. Open Education Research, 22, (1), 18-26.

[2] Gerstein, J. 2011. The flipped classroom model: A full picture.

[3] Wang, L.L. 2017. A Design of SPOC-based Blended College English Teaching Model. Heilongjiang Researches on Higher Education, (10), 168170.

[4] Lv, T.T. 2015. A Study on the Flipped Classroom Based College English Autonomous Learning Mode. Foreign Languages in China, 13, (1), 77-83.

[5] Chen, L., Chen, Y.H., Li, K.K., Zhao, M.M. 2016. The Development of Wisdom Courses as the Core of Wisdom Education. Modern Distance Education Research, 139, 33-40.

[6] Xue, Y., Zheng, L. 2016. Exploration and Reflection of SPOC: Based Teaching Model in Flipped Classroom. China Educational Technology, 352, 132-137. 